\title{
Automated irrigation system based on soil moisture using arduino board
}

Safwan A. Hamoodi, Ali N. Hamoodi, Ghanim M. Haydar

Engineering Technical College, Northeren Technical University, Iraq

\begin{tabular}{|c|c|}
\hline Article Info & ABSTRACT \\
\hline Article history: & In recent years, the best system of irrigation is studied by reducing \\
\hline Received Aug 24, 2019 & the wasted amount of water and electricity. Automatic irrigation is the use \\
\hline Revised Nov 12, 2019 & from one bay, or set of bays, to another can occur in the absence \\
\hline Accepted Feb 27, 2020 & $\begin{array}{l}\text { of the irrigator. In this work, automatic control system of solar irrigation } \\
\text { implemented practically using arduino board. This photovoltaic (PV) system }\end{array}$ \\
\hline Keywords: & $\begin{array}{l}\text { is applied in the garden of Engineering Technical College-Mosul (city in } \\
\text { Iraq). PV system can be adjusted by many regions in Iraq where it planned to }\end{array}$ \\
\hline $\begin{array}{l}\text { Arduino } \\
\text { Automatic control system }\end{array}$ & $\begin{array}{l}\text { connect on small part of land. Irrigation process is controlled depending on } \\
\text { moisture sensor that connected to sense the soil moisture and giving data to } \\
\text { arduino read pin. According to the program that uploaded to arduino, }\end{array}$ \\
\hline DC water pump & DC pump can be controlled as ON-state or OFF-state as respect to the soil \\
\hline Moisture sensor & moisture percentage ratio. Finally, the practical results are approximately \\
\hline Solar irrigation & similar to that obtained from proteus arduino simulator. \\
\hline
\end{tabular}

This is an open access article under the CC BY-SA license.

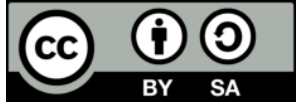

Corresponding Author:

Ali N. Hamoodi,

Engineering Technical College,

Northeren Technical University, Mosul, Iraq.

Email: alinhamoodi65@gmail.com

\section{INTRODUCTION}

Recently, the best method of irrigation is studied by reducing the wasted amount of water and electricity. Automated spray irrigation sort can be achieved depending on moisture sensor, this moisture sensor is connected to the controller in order to measure soil moisture content in the root zone. In order to avoid the high moisture regions, sensor must be placed at least five feet from the down pouts. This type of irrigation helps electrical power by degrading utilization from the power network and storing water by degrading the losses in water [1-7]. PV water pumping system is suitable for far location where no grid electricity is found; therefore, solar system must be installed and operating on solar energy. Solar pump is supplied by PV cells and streaming rate is calculated depending on sun ray light intensity [7-12]. For agricultural purposes an $85 \%$ of freshwater inflows we used. Due to population increases the percentage of water will be run on to be specialized in water consumption, so that it is necessary to design technical strategies depending on technology and science for persistent us e of water [13-18]. The arduino controller dispose as the focal for the robotic process after it was released the soil moisture by a sensor [19].

Farmers are always control the electric motors by observation the soil condition this method may be give correct or not correct indication therefore, the amount of water for true irrigation and for optimal growth of grass cannot be determined, moisture sensor is used to solve this problem [20]. In [21] a variable ascites system that apply to minimize the depending on rain and in general, the systems of irrigation are manually operates based ON/OFF scheduling control. In [22], the electric motors controlled by farmers to observe weather condition, grads by visiting the soil sites. In [23], the design of self-automatic system for irrigation 
is implemented by confirming the proper water level in order to grow up the plants through the four seasons, these automatic ascites plants usually confirm the suitable level of water in the locations when the grower are away. In [24], 8051 microcontroller is used for irrigation projects. The disadvantages of this microcontroller have signal processing and operating speed not good as arduino controller.

\section{METHODOLOGY}

\subsection{Problem definition}

Many systems that used for garden irrigation are located on the fare ways of cities and difficult to monitor therefore, manual operation will cause many problems [25].

\subsection{Proposed model}

In this following work, solar irrigation plant is proposed with automated controlled system. The data about the proper level of water in engineering technical college-Mosul garden are collected by moisture sensor and update the farmer as well as the arduino kit. In the past, the DC pump can be switch ON or OFF by the farmers depending on the water level, but now, when the water arrives until lethality level, DC pump will start automatically to confirm the best level of water in the garden [8]. A proposed irrigation system is illustrated in Figure 1.

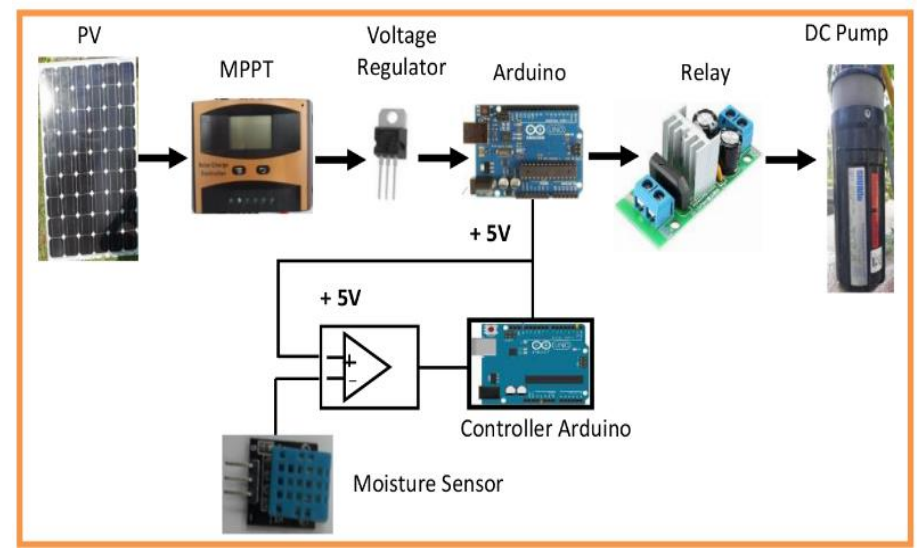

Figure 1. Block diagram of irrigation system

\subsection{Components \& materials}

The irrigation process is achieved practically depending on solar energy with the following materials and components as shown in Figure 2. The practical automatic plant watering system that used in this work is designed based on hardware and software.

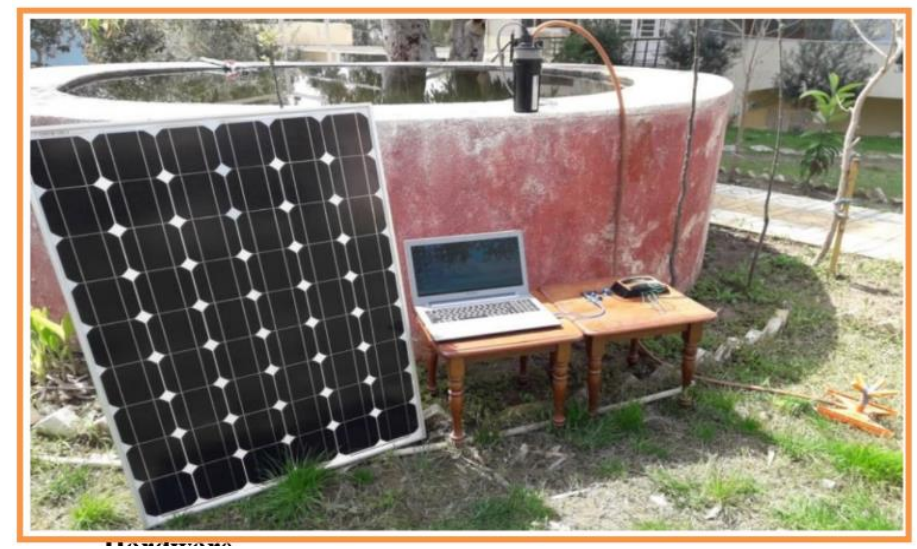

Figure 2. Components of the irrigation plant 


\subsubsection{Hardware}

The hardware elements that used in the garden watering system of engineering technical college-are given in table 1.

Table 1. Hardware elements

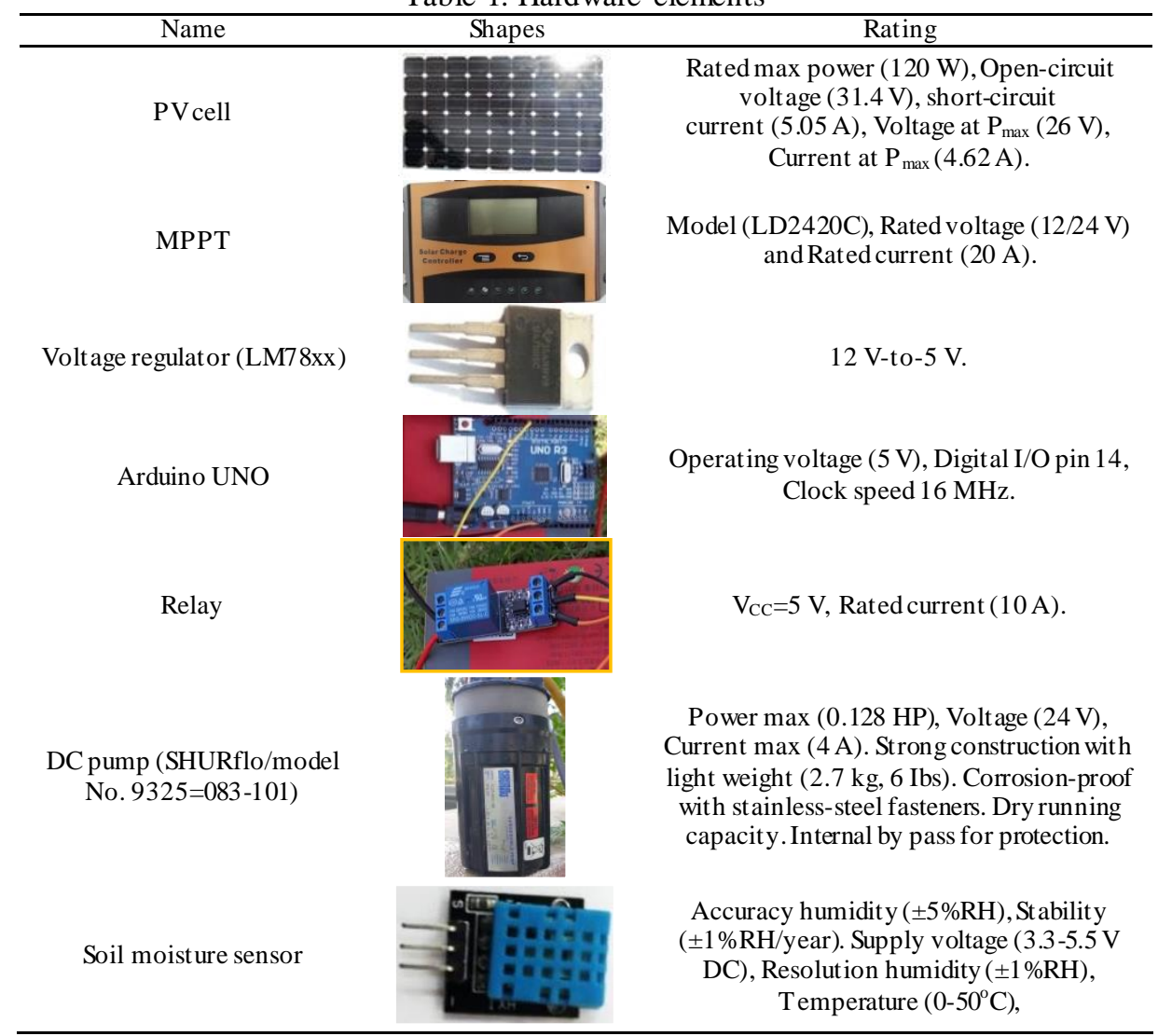

\subsubsection{Software}

Arduino IDE: The watering system (Irrigation system) code is written on arduino window and uploads it to the $\mathrm{I} / \mathrm{O}$ board.

\section{RESULTS}

\subsection{Soil moisture}

The international table of soil moisture ration among two seasons for one year is given in Table 2 [12]. Advantages of moisture sensor. The advantages of moisture sensor are [15]:

- Improving the growth

- Save time \& water

- Adaptable

- Discourages weeds

- Prevent or eliminate manual operation

- Helps to control on fungal diseases

Table 2. Soil humidity ratio for two seasons in one year

\begin{tabular}{|c|c|c|c|c|c|c|c|c|c|}
\hline Water depth in Cans (inch) & $1 / 8$ & $3 / 16$ & $1 / 4$ & $5 / 16$ & $3 / 8$ & $1 / 2$ & $5 / 8$ & $3 / 4$ & 1 \\
\hline \multicolumn{10}{|c|}{ Time of watering ( $\mathrm{min})$} \\
\hline Summer & 15 & 20 & 25 & 30 & 40 & 50 & 60 & 80 & 120 \\
\hline & 8 & 10 & 12 & 15 & 20 & 25 & 30 & 40 & 60 \\
\hline Fall water every $5-8$ days $(-0.75)$ inch & 12 & 15 & 18 & 23 & 30 & 38 & 45 & 60 & 90 \\
\hline
\end{tabular}




\subsection{Plant optimization algorithm}

The irrigation procedure is achieved step by step to get an economic valuation of time and water resources in agriculture as shown in Figure 3.

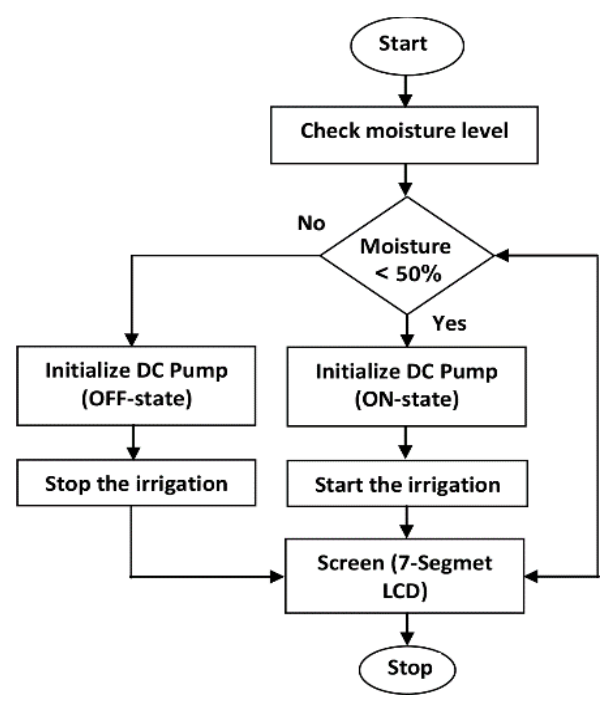

Figure 3. Irrigation procedures flowchart

\subsection{Advantages of automatic irrigation control}

The advantages of automatic control on grass irrigation are gardening flexibility, conserves water and time, preserves soil structure prevents weeds and prevents disease [16].

\section{PROTEUS ARDUINO SIMULATOR}

The materials which used in the garden irrigation are simulated by proteus arduino simulator, shown in Figure 4, where each device and element is connected and the moisture sensor represented as a resistive divider. The divider output voltage is applied to the arduino input which in turn read this voltage which express on a soil moisture percentage ratio display on LCD screen. After uploaded irrigation program on the arduino chip DC pump will be operate (irrigation) or will be stop (no irrigation) depending on moisture ratio limit in the program. The percentage ratio limit of soil moisture for permitting to DC pump to irrigate garden grass with water or stopping DC pump is (50\%).

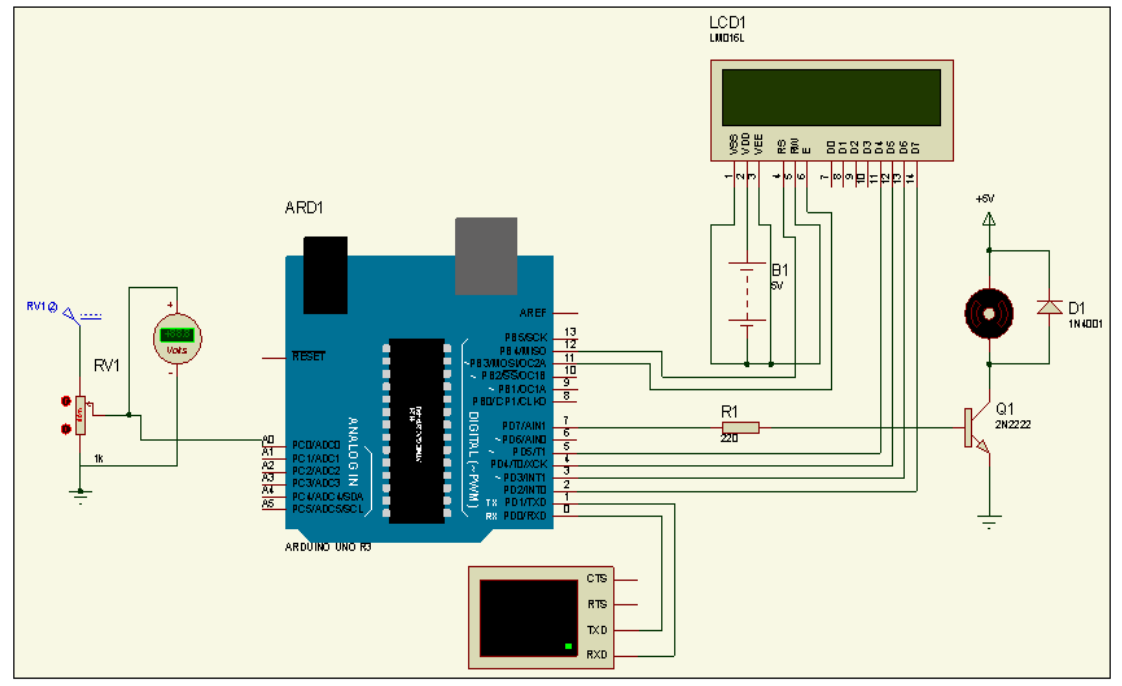

Figure 4. Proteus arduino hardware 
From the practical measurements that carried out on the soil of engineering technical college-Mosul, the relationship between sensor output voltage $(0 \mathrm{~V}-4.2 \mathrm{~V})$ and the percentage ratio of soil moisture that measured by the same sensor is illustrated in Table 3. The relationship between sensor voltage and soil moisture can be represented by a linear variation curve as depicted in Figure 5. From the proteus modeling (see Figures 6 and 7), when the soil moisture percentage ratio become $20 \%$ and $40 \%(<50)$ the DC pump had been ran. From proteus modeling (see Figures 8 and 9), when the soil moisture percentage ratio become $60 \%$ and $80 \%$ DC pump had been stopped.

In agricultural aspect the application of greenhouse observing is immense. Monitoring system for automated garden irrigation will help to reduce the workloads and efforts of human. It is ability to control demand depending on moisture sensor that connected to arduino read pin.

Table 3. Sensor voltage V soil moisture (\%)

\begin{tabular}{lcccccccccc}
\hline Sensor voltage $(\mathrm{V})$ & 0.42 & 0.84 & 1.26 & 1.68 & 2.10 & 2.52 & 2.94 & 3.36 & 3.78 & 4.20 \\
\hline Soil moisture $(\%)$ & 10 & 20 & 30 & 40 & 50 & 60 & 70 & 80 & 90 & 100 \\
\hline
\end{tabular}

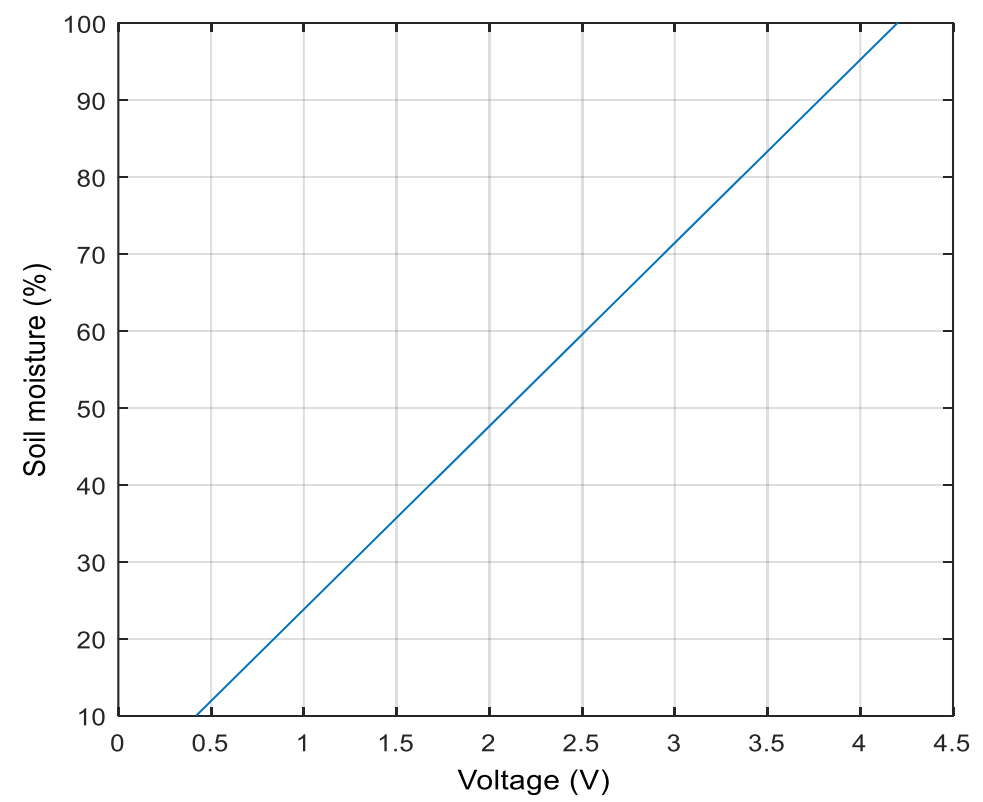

Figure 5. Voltage sens or V soil (\%) moisture

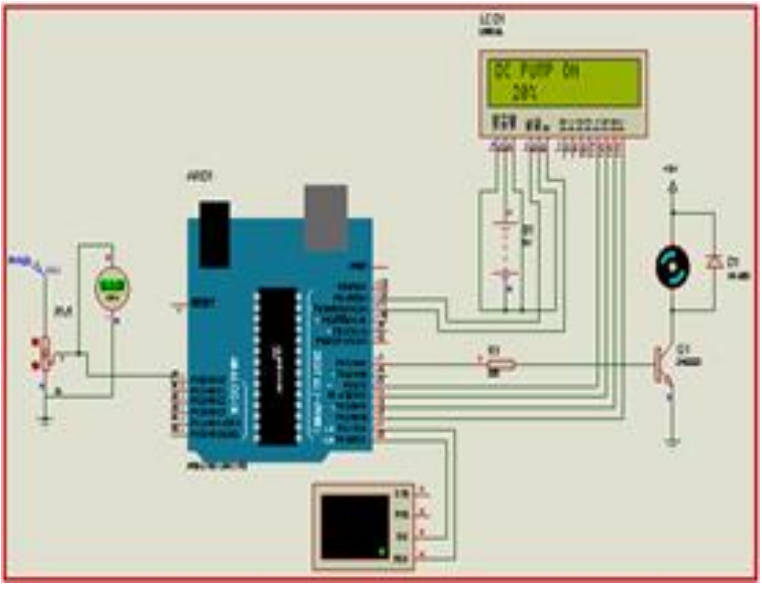

Figure 6. Circuit modeling at voltage 0.84 with soil moisture $20 \%$

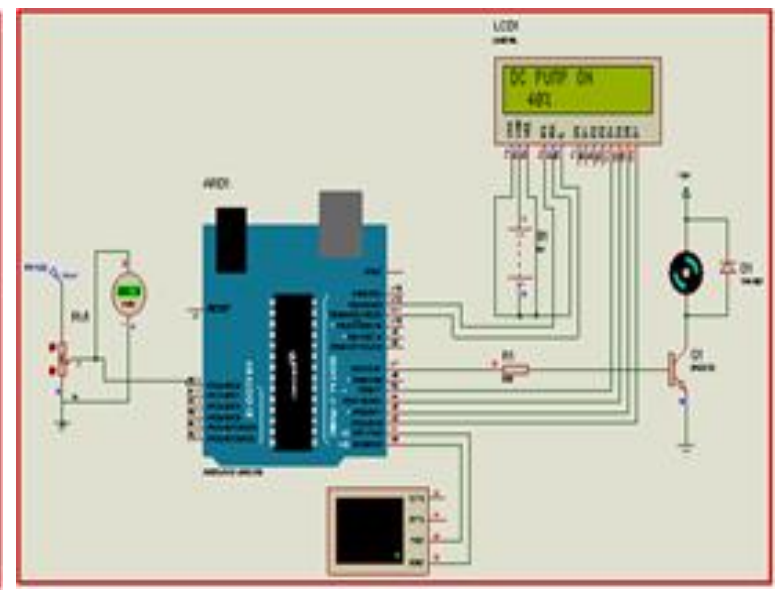

Figure 7. Circuit modeling at voltage 1.68 with soil moisture $40 \%$ 


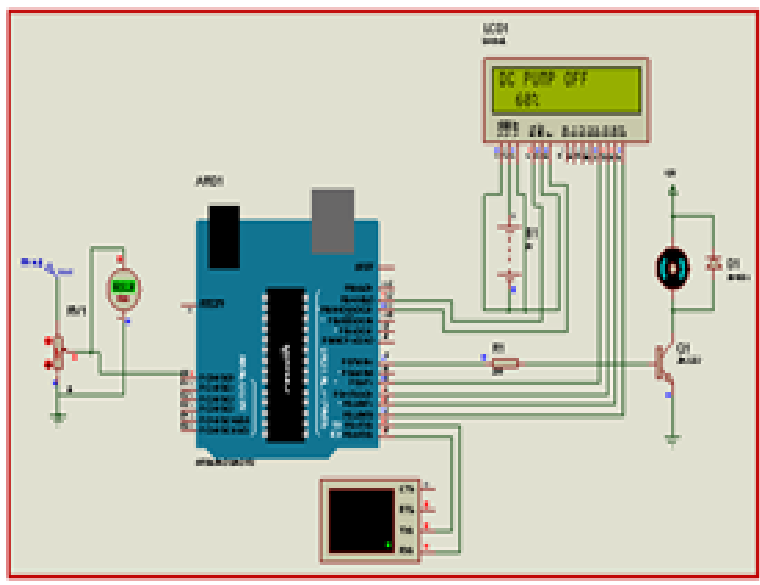

Figure 8 . Circuit modeling at voltage 2.52 with soil moisture $60 \%$

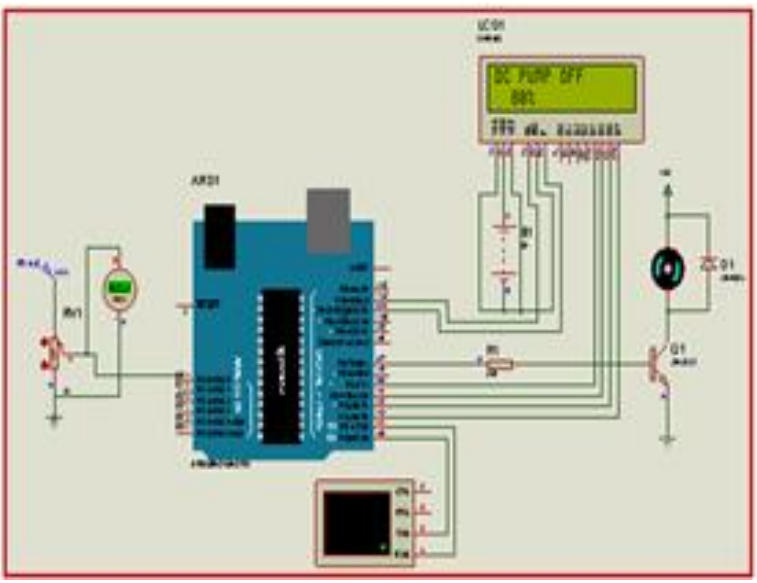

Figure 9. Circuit modeling at voltage 3.36 with soil moisture $80 \%$

\section{CONCLUSION}

PV system can be adjusted by many regions in Iraq where it planned to connected on small part of land. It is also this system concentered as eco-friendly. The proposed work has been existent to be verifying for optimizing water sources for is feasible for all type of grass. No battery storage system needed because at sunshine PV system will able to irrigate the garden and at rain weather the soil moisture enough to feed the roots of grass. Little maintains required, because only PV cell cleaning must be done. No inverter is required, because DC pump is used for irrigation process.

\section{DATA TYBE}

The data used to sustain the discoveries of this study are currently under prohibition while the enquiry findings are commercialized. Requests for data, [6/12 months] after publication of this article, will be considered by the corresponding author.

\section{CONFLICT OF INTERESTED FUNDED}

The employer here represents the promotor division in my university Northern Technical University which gives us the approval and the decision to publish our academic paper in your journal. The academic history of DC pump is the elementary electromagnetic principles were finding in the early 1800 by Oersted, Ganss, and Faraday. By 1820, Hans Christian Oersted and Andre Marie Ampere hand finding that an electric current produces a magnetic field. The authors declare that there is no conflict of inferest regarading the publication of this paper (our paper can be useful for academic studies).

\section{ACKNOWLEDGEMENTS}

We offer our special thanks to our Northern Technical University/Engineering Technical College-Mosul that gives us the occasion to do this wonder full project on the topic.

\section{REFERENCES}

[1] A. Prathyusha, and C. Suman, "Design of embedded system for automation of drip irrigation," International Journal of Application or Innovation in Engineering \& Measurement (IJAIEM), vol. 1, no. 2, pp. 254-258, 2012.

[2] S. Harishankar, et al., "Solar powered smart irrigation system," Advance in Electronic and Electric Engineering, vol. 4, no 4, pp. 341-346, 2014.

[3] Engr. Umer Mehmood, "Pilot testing of solar water pumps," Presentation, Directorate General Agriculture (Water Management), Punjab, 2010.

[4] P. E. Chris Callahan and B. Waterman, "Solar water pumping basics," UVM Extension New Farmer Project, pp. 1-9, 2013.

[5] T. D. Morales, and J. Busch, "Design of small photovoltaic (PV) solar-powered water pump systems," Technical, Note No. 28, United States Department of Agriculture, Washington DC, pp. 55-71, 2010. 
[6] A. U. Rehman, et al., "GSM based solar automatic irrigation system using moisture, temperature and humidity sensors," International Conference on Engineering Technology and Technopreneurship (ICE2T), Kuala Lumpur, pp. 1-4, 2017.

[7] S. V. Deshpande, et al., "Solar powered automated irrigation sy stem," IJARIIE, vol. 4, no. 2, pp. 3508-3511, 2018.

[8] L. Prisilla, et al., "A noval method for water irrigation system for paddy fields using ANN," International Journal of Computer Science and Network (IJCSN), vol. 1, no. 2, 2012.

[9] L. Longchang and W. Yanjun, "Pipeline water delivery technology," China Water Power Press, pp. 33-35, 1998.

[10] R. Karthikeyan, et al., "Wireless sensor networks for efficient irrigation system using hybrid pv-wind system," International Conference on Advances in Electrical Engineering (ICAEE), Vellore, pp. 1-5, 2014.

[11] M. R. Mahadev, et al., "Arduino automatic plant irrigation using message alert based," International Journal for Innovative Research in Science \& Technology (IJIRST), vol. 4, no. 12, 2018.

[12] M. Montazeri-Gh and M. Mahmoodi-k, "Development a new power management strategy for power split hybrid electric vehicles," Transportation Research Part D: Transport and Environment, no. 37, pp. 79-96, 2015.

[13] N. Kyei-Baffour, "Future irrigation prospects and actions in Ghana," Proceedings of the 1st National Conference on Agricultural Engineering at the Department of Agricultural Engineering, KNUST, Kumasi, pp. 65-75, 1994.

[14] M. M. Memuna and O. O. Cofie, "Effects of farming practices on the performance of rise (Oryza sativa) in selected farms of Ashaiman Irrigation project," Hunger without Frontiers, GSAE/WASAE, Ghana, pp. 244-254, 2005.

[15] S. Bagal, et al., "Arduion based automatic plant watering system," International Journal Engineering Science and Computing (IJESC), vol. 8, no. 3, pp. 16342-6344, 2018

[16] Kole, "Automatic irrigation system," Thesis, Electrical Engineering, RCC Institute of Information Technology, 2018

[17] M. Hoseinzadeh and S. janipour, "Waste minimization in paint manufacturing plants: cost saving and environmental protection," UCT Journal of Research in Science, Engineering and Technology, vol. 3, no. 3, pp. 36-40, 2015.

[18] R. Keerthana, et al., "Design of planar antenna using micro strip feed for biomedical applications," International Journal of Communication and Computer Technologies, vol. 5, no. 5, pp. 76-81, 2017.

[19] Y. Venkateswararao and K. Sujana, "A novel stability indicating Rp-Hplc method development and validation for the determination of clopidogrel in bulk and its dosage forms," International Journal of Pharmacy Research \& Technology, vol. 9, pp. 1-11,2019.

[20] B. P. Marques, et al., "Student activity analytics in an e-learning platfom: Anticipating potential failing students," Journal of Information Systems Engineering \& Management, vol. 3, no. 2, 2018.

[21] M. D. Farahani and H. Shahsavari, "GIS modeling of earthquake damage zones using ETM data and remote sensingBojnoord, Khorasan Province," UCT Journal of Research in Science, Engineering and Technology, vol. 2, no. 2, pp.47-51, 2014.

[22] E. Zineb, et al., "The impact of SCRM strategies on supply chain resilience: A quantitative study in the Moroccan manufacturing industry," International Journal of Supply Chain management, vol. 6, no. 4, pp. 70-76, 2017.

[23] S. Hilday anti and J. Alie, "Factors influenced paddy farmers to use or not use organic fertilizers in South Sumatera, Indonesia," Humanities \& Social Sciences Reviews, vol. 4, no. 1, pp. 53-58, 2016.

[24] M. Rizwan, et al., "Ideology and politics of Jamiat Ulema-i-Islam (1947-1973)," Global Social Sciences Review (GSSR), vol. 3, no. 1, pp. 45-56, 2018.

[25] S. Panigrahi and A. Thakur, "Modeling and simulation of three phases cascaded H-bridge grid-tied PV inverter," Bulletin of Electrical Engineering and Informatics, vol 8, no. 1, pp 1-9, 2019. 